\title{
PREVALENCE OF COCCIDIOSIS IN SONALI BIRDS IN SIRAJGONJ DISTRICT OF BANGLADESH
}

\author{
S. M. S. H. Belal
}

Veterinary Surgeon (Leave Reserve), Department of Livestock Services, Dhaka, Bangladesh

\begin{abstract}
The study was conducted to ascertain the prevalence of coccidiosis in Sonali birds in Sirajgonj district of Bangladesh during the year 2015-2016. Diagnosis was made on the basis of history, clinical and post mortem findings. A total of 660 samples (sick and dead birds) were examined where 234 (35.45\%) samples were found positive for coccidiosis. The highest prevalence percentage was found in July $(53.33 \%)$ and the lowest percentage was found in January (16.67\%). Birds aged 5 to 6 weeks showed more prevalence percentage $(47.50 \%)$, whereas older birds $(>16$ weeks) found less susceptible $(10 \%)$ to coccidiosis. Coccidiosis was slightly more prevalent in female $(37.70 \%)$ than male $(32.22 \%)$.
\end{abstract}

Keywords: Coccidiosis, Sonali birds, prevalence, Sirajgonj.

\section{INTRODUCTION}

Bangladesh is a densely populated country having 161 million people. They mostly rely on livestock and poultry for their protein requirement. The demand for meat is 7.05 million metric ton, and of egg is 16744 million in number. But, due to inability of the country's total livestock and poultry population to produce the required quantity of these products, there is a shortfall. The deficits of the meat is 0.9 million metric ton, and of the eggs is 4831.60 million a year (DLS, 2016). Additionally, people of this country are accustomed to have meat from our indigenous chicken; thus, many of them, with a claim of less taste, are reluctant to take hybrid chicken like broiler. The situation that prevailed in the country directed Bangladeshi researchers to develop a breed having meat's taste similar to our indigenous birds. The Sonali birds introduced in 1996-2000 in Northern part of Bangladesh through SLDP (Smallholder Livestock Development Project) and PLDP (Participatory Livestock Development Project) is a cross-breed of Rhode Island Red (RIR) cocks and Fayoumi hens having similar phenotypic appearance of local chickens of Bangladesh (Uddin et al., 2015). It constitutes about 35 percent of the country's total commercial broiler and layer production (Huque, 2011).Because the Sonali chickens are well adapted in the environmental conditions of Bangladesh, it requires less care and attention, and hence easier for women to rear (Saleque and Saha, 2013). However, these birds are vulnerable to several threats including coccidiosis. Coccidiosis is a protozoan disease of poultry caused by single-celled protozoan parasites of the genus Eimeria. The disease is more severe in Sonali birds where the rate of morbidity and mortality is high. It is characterized by dysentery, enteritis, diarrhea which may be bloody with certain Eimeria species, emaciation, lowered feed conversion rate, delayed sexual maturity, drooping wings, poor growth and low production (Rehman et al.,2010; Awais et al., 2012) with attendant high mortality and morbidity rates (Shirzad et al., 2011). The most common and pathogenic species that affects the poultry industry globally is the E. tenella ( Ayaz et al., 2003) with $100 \%$ morbidity and a high mortality due to extensive damage to the digestive tracts of chickens (Hadipour et al., 2011). Mortality rates are usually high in young chicks, because most of the Eimeria species affect birds between 3 and 18 weeks of age (Nematollahi et al., 2009; Dakpogan et al., 2013). Depression of production, in addition to chicken death, is the cause of economic loss which depends on disease prevalence. Prevalence is the number of existing cases of a disease or occurrences of an event during a particular period. Prevalence is expressed as a proportion in which the number of events is the numerator and the population at risk is the denominator. Prevalence of coccidiosis in this area refers to the total number of cases occurred throughout the study period in total Sonali population of Sirajgonj, Bangladesh.

*Corresponding e-mail address: shariful.belal@yahoo.com 
Sirajgonj district is situated in Rajshahi Division of Bangladesh where the number of Sonali birds is increasing rapidly, and it has become both a source of income generation for farmers and a way of providing protein for the people. However, no research has been undertaken to know the prevalence of coccidiosis in this birds of this district. Thus, this study was aimed at determining the prevalence of coccidiosis in Sonali birds in Sirajgonj district of Bangladesh.

\section{MATERIALS AND METHODS}

\section{Study area and duration}

The study was conducted in all nine upazilas of Sirajgonj district of Bangladesh during July 2015-June 2016. Its geographical coordinates are $24^{\circ} 27^{\prime} 0^{\prime \prime}$ North, $89^{\circ} 43^{\prime} 0^{\prime \prime}$ East. Sirajgonj has an area of 2,498 Sq.km (964 sq miles) including riverine areas, and it represents around 1.7 percent of the total area of Bangladesh. The annual average temperature of the district reaches a maximum of $34.6{ }^{\circ} \mathrm{C}$, and a minimum of $11.9^{\circ} \mathrm{C}$. The annual rainfall is $1610 \mathrm{~mm}$ (63.4 inches).The average relative humidity is $72.77 \%$.

\section{Study animals, population and sampling}

The study was performed in Sonali chickens dividing them in three age groups raised in intensive management system. Both sexes were considered in this study. About 660 flocks from nine upazila were examined each having approximately 500 to 2500 birds. A total of 660 samples (sick and dead birds), in addition to the feces, were taken and subjected for further study. The size of the samples from different upazila was determined on the basis of the size and density of poultry population of that upazila.

\section{Examination of the samples}

After recording patient details e.g. age, sex, morbidity, mortality, and clinical findings, all dead birds were subjected to routine postmortem examination. Visceral organs were thoroughly examined for gross pathological changes at the District Veterinary Hospital, Sirajgonj, Bangladesh. All parts of intestine were examined carefully for the presence of lesions, blood and cecal-core formation. Intestinal scrapings were collected and examined under the microscope for the presence of oocyst and asexual forms of Eimeria. The fecal samples were examined by the flotation method using saturated solution of sugar (Sharma et al., 2013; Gharekhani et al., 2014) for the identification of oocyst. For the oocyst to quantify, the modified McMaster technique was employed. Sporulations were performed by placing the samples in Petridishes, with a $2.5 \%$ potassium dichromate solution at room temperature airing daily for up to two days (Gari et al., 2008). The species of Eimeria were determined based on morphology of oocysts, sporocysts (shape, color, form index, micropyle, and presence or absence of residual body) and time of sporulation (Soulsby, 1982).

\section{RESULTS AND DISCUSSION}

In this study, the overall prevalence rate was found to be 35.45.This is lower than findings reported by Jatau et al. (2012) in Zaria, and Olanrewaju and Agbor (2014) in Abuja, Nigeria which were $37.1 \%$ and 69\% respectively. But, it is higher than $11.4 \%, 14 \%$ and $31 \%$ as reported by Grema et al. (2014) in Gombe, Adamu et al.(2008) in Sokoto state and Lunden et al. (2010) respectively. However, this finding is similar to the prevalence rate of $36.6 \%$ observed by Dakpogan and Salifou (2013).The variation in the findings might be due to different factors, such as sampling periods, sample size, geographical area, density of the population, and climatic conditions prevailing in the study area. The prevalence rate of coccidiosis in younger (1-4 weeks), grower (5-16 weeks), and adult birds ( $>16$ weeks) was $23.75 \%$, $47.50 \%$ and $10 \%$ respectively (Table 1).The rate is higher in grower than adult and chick. Khaled et al. (2016) found higher rate of coccidiosis in growing birds. The result was agreed with other researchers (Olanrewaju et al., 2014; Gharekhani et al., 2014; Oljira et al., 2012; Muazu et al., 2008, and Khan et al., 2006).This higher rate of coccidiosis in the growing birds might be due to lack of maternal immunity as well as lack of previous exposure to infection. Sharma et al. (2013) reported higher prevalence of coccidiosis in the age group of 31-45 days. The prevalence rate of coccidiosis in younger (1-4 weeks) birds is found higher than older birds. This result is agreed with the findings of Omer et al. (2011) who reported that all 
ages of birds are susceptible to coccidiosis, but younger birds are more susceptible to infection than older birds usually because of keeping them under deep litters made of wood shavings for several weeks during the brooding period when the chance of oocysts ingestion is high. On the contrary, it is lower than in grower birds since it is getting protected for up to 15 days post hatching. The older birds are resistant to infection due to development of immunity from first infection and hence, this rate (10\%) is the lowest among the groups.

The prevalence rate of coccidiosis was found to be relatively higher in female $(37.70 \%)$ than male $(32.22 \%)$ birds (Table1).This high rate might be due to stress during egg production and malnutrition resulting from competitive feed intake with male birds raised in the same deep litter. However, this rate is not statistically different indicating both sexes have equal chances of acquiring and becoming infected with Eimeria oocysts during feeding or in an outbreak scenario, which is consistent with previous studies (Oljira et al., 2012; Alemayehu et al., 2012; Naphade et al., 2013).

This study revealed that coccidiosis occurs in all months of the year with different frequency (Table 2). The incidence rate was high in the months of July, August and September with highest in July, when the relative humidity, temperature and rainfall were $80 \%, 28.50$ degree centigrade, and $354 \mathrm{~mm}$ respectively. The reversed incidence rate was observed in the months of January, February and March with the lowest in January when the relative humidity, temperature and rainfall were 51\%, 18.40 degree centigrade and $14 \mathrm{~mm}$ respectively. So, the weather forecast of Sirajgonj district during study period showed that there was a strong relationship among the occurrence of the coccidiosis, relative humidity, temperature, and rainfall. These findings go with the findings of the other researchers (Haug et al., 2008; Bachaya et al., 2012; Sharma et al., 2013; Khan et al., 2006) where they stated that high humidity and rainfall caused increased number of oocyst to sporolate resulting in the increased prevalence rate of coccidiosis.

Table 1. Prevalence of coccidiosis on the basis of age and sex

\begin{tabular}{lccc}
\hline Risk Factors & No. of samples examined & No. of positive cases & Prevalence rate (\%) \\
\hline Age (weeks) & & & 23.75 \\
Young(1-4) & 240 & 57 & 47.50 \\
Grower(5-16) & 360 & 171 & 10.00 \\
Adult( $<16)$ & 60 & 6 & 32.22 \\
Sex & & & 37.70 \\
Male & 270 & 87 & 147 \\
Female & 390 & 147 & \\
\hline
\end{tabular}

Table 2. Prevalence of coccidiosis on the basis of time of the year

\begin{tabular}{cccc}
\hline Risk Factors & No. of samples examined & No. of positive cases & Prevalence rate $(\%)$ \\
\hline January & 36 & 06 & 16.67 \\
February & 57 & 12 & 21.05 \\
March & 39 & 12 & 30.76 \\
April & 102 & 33 & 32.35 \\
May & 72 & 18 & 25.00 \\
June & 81 & 30 & 37.03 \\
July & 45 & 24 & 53.33 \\
August & 63 & 33 & 52.38 \\
September & 30 & 15 & 50.00 \\
October & 39 & 18 & 46.15 \\
November & 51 & 21 & 41.18 \\
December & 45 & 12 & 26.67 \\
\hline Total & 660 & 234 & 35.45 \\
\hline
\end{tabular}




\section{S. M. S. H. Belal}

\section{ACKNOWLEDGEMENTS}

The author is grateful to Md. Mazharul Alam Akanda, ex- DLO, Sirajgonj for providing the facility to perform research work. The author is also thankful to Md. Abu Sayed Talukder, District Livestock Office, Sirajgonj for his great help in collecting samples.

\section{REFERENCES}

1. Awais MM, Akhtar M, Iqbal Z, Muhammad F and Anwar MI ( 2012).Seasonal prevalence of coccidiosis in industrial broiler chickens in Faisalabad, Punjab, Pakistan. Tropical Animal Health and Production 44: 323-328.

2. Ayaz M, Akhtar M, Hayat CS, Hafeez MA and Haq A (2003). Prevalence of coccidiosis in broiler chickens in Faisalabad, Pakistan. Pakistan Veterinary Journal 23: 51-52.

3. Adamu AY, Ahmed AB, Abubakar MB and Lawal MD (2009). A retrospective study (2004-2008) of poultry diseases diagnosed in veterinary teaching hospital (VTH), Usmanu Danfodiyo University Sokoto (UDUS) and Sokoto Veterinary Centre (SVC), Sokoto State, Nigeria. International Journal of Animal and Veterinary Advances 1: 15-17.

4. Alemayehu T, Tekeselassie A and Kassa SA (2012). Prevalence study of poultry coccidiosis in small and large-scale farms in Addis Ababa, Ethiopia. Scientific Journal of Crop Science 1: 26-31.

5. Bachaya HA, Raza MA, Khan MN, Iqbal Z, Abbas RZ, Murtaza S and Badar N (2012). Predominance and detection of different Eimeria species causing coccidiosis in layer chickens. Journal of Animal and Plant Sciences 22: 597- 600

6. Dakpogan HB and Salifou S (2013). Coccidiosis prevalence and intensity in litter based high stocking density layer rearing system of Benin. Journal of Animal and Plant Sciences. 17: 2522-2526

7. DLS (2016). Livestock Economy at a Glance, Report of the Department of Livestock Services, Dhaka, Bangladesh. Website: dls.portal.gov.bd

8. Grema HA, Suleiman A, Rabana JL and Geidam YA (2014). A six-year (2005-2010) retrospective study of avian coccidiosis diagnosed in Gombe veterinary clinic, Nigeria. Sokoto. Journal of Veterinary Science. 12: 8-13.

9. Gari G, Tilahun G and Dorchies P (2008). Study on poultry coccidiosis in Tiyo District, Arsi Zone, Ethiopia. International Journal of Poultry Science 7: 251-256.

10. Gharekhani J, Sadeghi-Dehkordi J and Bahrami M (2014). Prevalence of coccidiosis in broiler chicken farms in Western Iran. Journal of Veterinary Medicine Article ID 980604, 4 pages.

11. Haug A, Gjevre AG, Thebo P, Mattsson JG and Kaldhusdal M (2008). Coccidial infections in commercial broilers: epidemiological aspects and comparison of Eimeria species identification by morphometric and polymerase chain reaction techniques. Avian Pathology 37: 161-170.

12. Huque QME (2011).Commercial poultry production in Bangladesh. Souvenir of the $7^{\text {th }}$ International Poultry Show and Seminar, 25-27 March, 2011, Dhaka, Bangladesh.

13. Hadipour MM, Olyaie A, Naderi M, Azad F and Nekouie O (2011). Prevalence of Eimeria species in scavenging native chickens of Shiraz, Iran. African Journal of Microbiology Research 5: 3296-3299.

14. Jatau ID, Sulaiman NH, Musa IW, Lawal AI, Okubanjo Isah OO and Magaji Y (2012). Prevalence of Coccidia infection and preponderance Eimeria species in free range indigenous and intensively managed exotic chickens during hot-wet season, in Zaria, Nigeria. Asian Journal of Poultry Science 6: 79-88.

15. Kaboudi K, Umar S and Munir MT (2016). Prevalence of Coccidiosis in Free-Range Chicken in Sidi Thabet,Tunisia. Scientifica article ID 7075195, 6 pages.

16. Khan MQ, Irshad H, Anjum R, Jahangir M and Nasir U (2006). Eimeriosis in poultry of Rawalpindi/Islamabad area. Pakistan Veterinary Journal 26: 85-87.

17. Lunden A, Thebo P, Gunnarson S, Hooshmand-Rad P, Tauson R and Uggla A (2010). Eimeria infections in litter-based, high stocking density systems for loose housed laying hens in Sweden. British Poultry Science 41: 440-447.

18. Muazu A, Masdooq AA and Ngbede J (2008). Prevalence and identification of species of Eimeria causing coccidiosis in poultry within Vom, Plateau state, Nigeria. International Journal of Poultry Science 7: 917-918.

19. Nematollahi A, Gholamali M and Reze FP (2009). Prevalence of Eimeria species among broiler chicks in Tabriz, Iran. Munis Entomology and Zoology 4: 53-58.

20. Olanrewaju CA and Agbor RY (2014). Prevalence of coccidiosis among poultry birds slaughtered at Gwagwalada main market, Abuja, FCT, Nigeria. International Journal of Engineering Science 3: 41-45. 
21. Omer SA, Apio A, Wronski T and Mohammad OB (2011). A new coccidian parasite (Eimeria farasanii n. sp.) indicates parasite-host specificity in endemic Farasan gazelle. International Journal of Zoology Research 7: 85-92.

22. Oljira D, Melaku A and Bogale B (2012). Prevalence and risk factors of coccidiosis in poultry farms in and around Ambo Town, Western Ethiopia, American-Eurasian Journal of Scientific Research 7: 146-149.

23. Rehman TU, Khan MN, Sajid MS, Abbas RZ, Arshad M, Iqbal Z and Iqbal A (2010). Epidemiology of Eimeria and associated risk factors in cattle of district Toba Tek Singh, Pakistan. Parasitology Research 108: 1171-1177.

24. Saleque MA and Saha AA (2013). Production and economic performance of small scale Sonali bird farming for meat production in Bangladesh. In proceedings of seminar of the 8th International Poultry Show and Seminar, Dhaka. World's Poultry Science Association Bangladesh pp 20-24.

25. Shirzad MR, Seifi S, Gheisari HR, Hachesoo BA, Habibi H and Bujmehrani H (2011). Prevalence and risk factors for subclinical coccidiosis in broiler chicken farms in Mazandaran province, Iran. Tropical Animal Health and Production 43: 1601-1604.

26. Sharma S, Iqbal A, Azmi S and Shah HA (2013). Study of poultry coccidiosis in organized and backyard farms of Jammu region. Veterinary World 6: 467-469.

27. Soulsby EJL (1982). Helminths, Arthropods, and Protozoa of Domesticated Animals, Lea \& Febiger, Philadelphia, USA. 809 pages

28. Uddin MT, Rahman MH, Saleque MA and Thieme O (2015). Comparative performance of Sonali chickens, commercial broilers, layers and local non-descript (deshi) chickens in selected areas of Bangladesh. FAO Animal Production and Health Working Paper No. 14, Rome. 